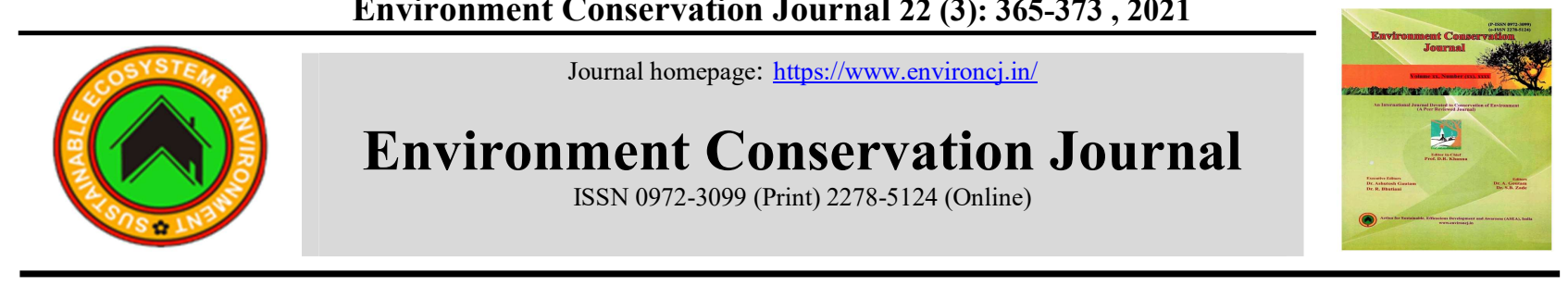

\title{
Influence of sulphur aerosols on physiological, yield and yield attributing of wheat (Triticum aestivum L.) using principal component analysis
}

\author{
Babithraj Goud Gaddameedi 的 \\ Department of Crop Physiology, PJTSAU, Agriculture College, Rajendranagar, Hyderabad, Telanagana, India \\ Bhagawan Bharali \\ Department of Crop Physiology, Assam Agricultural University, Jorhat, Assam, India \\ Soibam Helena Devi \\ Department of Crop Physiology, Assam Agricultural University, Jorhat, Assam, India
}

\begin{tabular}{|c|c|}
\hline ARTICLE INFO & ABSTRACT \\
\hline $\begin{array}{l}\text { Received : } 11 \text { July } 2021 \\
\text { Revised : } 12 \text { October } 2021 \\
\text { Accepted : } 24 \text { October } 2021 \\
\text { Available online: } 19 \text { December } 2021 \\
\text { Key Words: } \\
\text { Aerosols } \\
\text { Climate Change } \\
\text { PCA } \\
\text { S-aerosols } \\
\text { Sulphur } \\
\text { Wheat } \\
\text { Yield }\end{array}$ & 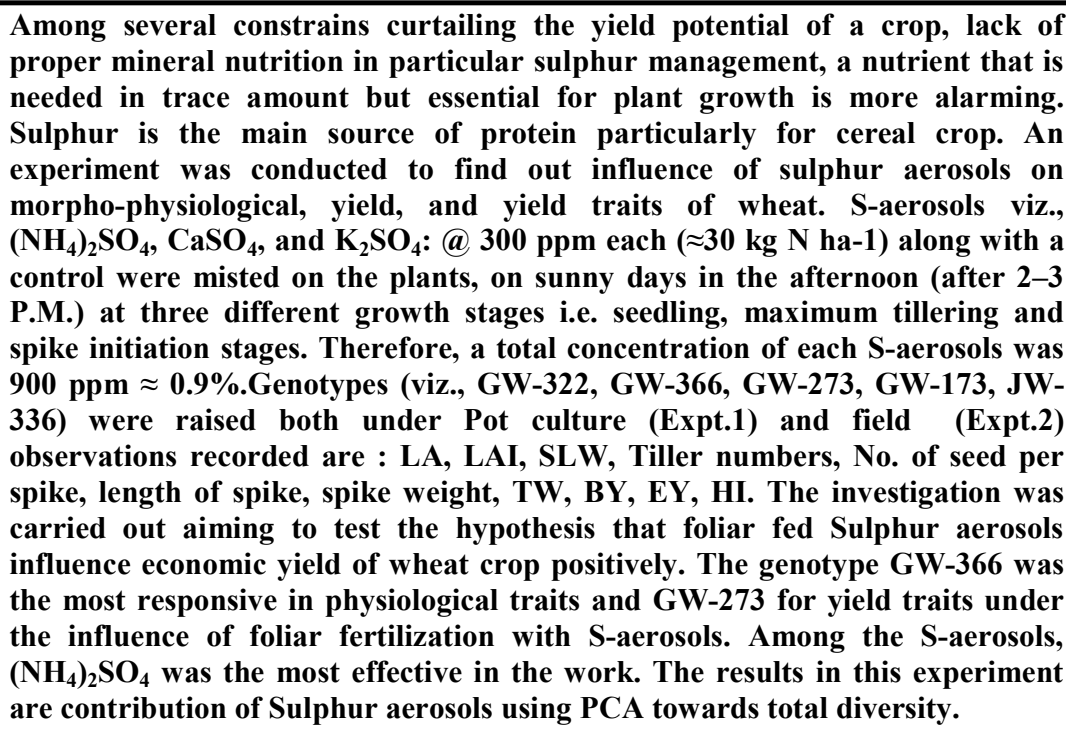 \\
\hline
\end{tabular}

\section{Introduction}

In past decades, growth of India's agricultural with an area of about $30.2 \mathrm{M}$. ha (DES 2017). sector, has been remarkable with almost five-fold increase in food grains production by last 50 years thereby, transforming India to a net food exporter (FAO-2017). India is one of the most popular country in the world comprising $18 \%$ of the global population with a food grain requirement of 109 MT, by the end of the year 2020, (Shoran et al., 2004) and is expected to reach to $1.7 \mathrm{~B}$ by 2050 (UN 2017) (Lobell et al., 2011; 2013; Burney and Ramanathan, 2014). Wheat is the main crop of India, rice-wheat cropping system with a current production of $98.4 \mathrm{MT}$, India is the second largest wheat producing country in the world (FAO 2018) Toxicity of Sulphur (caused by $\mathrm{SO}_{2}$ ) produces

Corresponding author E-mail: babithrajgoud963@gmail.com

Doi: https://doi.org/10.36953/ECJ.2021.22342

This work is licensed under Attribution-Non Commercial 4.0 International (CC BY-NC 4.0)

(C) ASEA 
chlorosis and interveinal necrosis in plants (Farooq and Hans 1999), which ultimately reducing growth and yield (Wali et al., 2004). Sulphur is assimilated in the form of cysteine which behaves as a precursor or reduced Sulphur donor of most other organic Sulphur compounds in plants. Cysteine also plays a critical role in protection against biotic/abiotic stress (Noctor et al., 2002).

Nitrogen $(\mathrm{N})$ and Sulfur $(\mathrm{S})$ supplies have a more influence on the wheat storage proteins by quality and quantity. Nitrogen derived from urea, $\mathrm{S}$ from micronized elemental sulfur, and a mixture of both application of $(\mathrm{N}+\mathrm{S})$ at anthesis stage on wheat by foliar spray. (Fageria et al., 2009) reported that when nutrients are applied to soils, they are absorbed by plant roots and translocated to aerial parts. In such, case of foliar application, the nutrients penetrate the cuticle of the leaf, the stomata and then enter the cells. Hence, crop response occurs faster, compared to soil application. Sulfur plays important role in wheat productivity as it is the constituent of several amino acids viz., methionine, cysteine, sulfolipds and coenzymes such as biotin, coenzyme-A, thiamine pyrophosphate and lipoic acid. But, little information is available on the influence sulphur on wheat applied in the form of aerosols.

\section{Material and Methods Experimental Site}

Field \& pot experiments were conducted at the ICR farm, AAU, Jorhat during the year 2017-18 (Expt.1) \& 2018-19 (Expt. 2).

\section{Experiment Design and Crop Management}

Pot \& Field experiments were conducted to study the yield related characters. Randomized Block Design (RBD) with two replications was followed in the experiment with spacing $(22 \mathrm{~cm}) \&$ seed rate $30 \mathrm{Kg} \mathrm{ha}^{-1}$.

\section{Misting of aerosols on plants}

The foliage of plants were misted with S-aerosols (a) $300 \mathrm{ppm}(\approx 30 \mathrm{~kg} \mathrm{~S}$ ha-1) at three growth stages of the crop viz., at seedling stage, maximum tillering stage and spike initiation stages. Each of the S-aerosol was applied in 3 splits on cloud free and clear sunny days in the afternoon when air temperature was low.

\section{pH of Aerosol}

A digital $\mathrm{pH}$ meter with standard $\mathrm{pH}(4 \& 7)$ was used to measure the $\mathrm{pH}$ of the S-aerosols which were found as distilled water: 7.00; $\left(\mathrm{NH}_{4}\right)_{2} \mathrm{SO}_{4}$ : (5.34); $\mathrm{CaSO}_{4}$ : (5.49), $\mathrm{K}_{2} \mathrm{SO}_{4}$ (5.66)

\section{Quantifying the following morphological and yield parameters}

Leaf area, Leaf Area Index, Specific leaf weight (SLW), Tiller number were recorded at maximum tillering and spike initiation stage. Number of seeds per spike, Length of spike, Spike weight, Test weight, Economical yield and Biological yield, Harvest Index were recorded at spike initiation stage. Leaf area was measured at maximum tillering and spike initiation stages. Fully expanded green leaves were selected at random from five plants per replication. The length and breadth of each leaf were measured and used for calculation of Leaf area at the respective stages. Leaf area index was measured by proportioning the leaf area to the ground area covered by the individual plant canopy. Specific leaf weights were calculated by taking total Leaf dry weight/ Area of leaf $\left(\mathrm{mg} \mathrm{cm}^{-2}\right)$ (Singh 1988). Number of tillers in five observational plants from each experimental plot was counted at maximum tillering and spike initiation stages of the crop. Random selection of five spikes, length of five spikes, and weight of five spikes, number of grains per spike was counted from field. Thousand seeds, Grain yield were randomly selected from each seed lot of individually harvested and thrashed out separately. Similarly, in case of pot experiment, too, economical yield, Biological yield was recorded from thrashed plants per pot. Harvest index (HI) suggested by Nichiporovich (1967)

\section{Statistical analysis}

Data for each plant parameter was analysed by Fisher's method variance (Panse and Sukhatme 1978).

\section{Principal Component Analysis (PCA)}

PCA makes it possible to transform a given set variables, which are mutually correlated, into a new system of characteristics, known as principal components, which are not correlated. The obtained variables may also be used for further analysis. Moreover, the analysis is characterized by the fact that it includes the total variance of variables, explains maximum of variance within a data set, and is a function of primary variables (Krzyśko et al., 2008; Gregorczyk et al., 2008). 


\section{Results and Discussion}

Different morpho-physiological and grain characteristics are studied using Principal component analysis (PCA) to know the major characteristics contributing to yield at different stages viz., seedling, maximum tillering and spike initiation stages.

The results of PCA at maximum tillering stage in field experiment of wheat varieties depicted that PC1 itself accounted 97.74 per cent of variation among all the principal components (PCs). Also, it had $>1.00$ eigen value (1.94) and it is significant among all 4 PCs (Table 1). PC1 is mainly correlated with leaf area and it is important component in $\mathrm{PC} 1$ with highest loading factor (0.92). So, leaf area is in direct relation with increase in the crop canopy with more number of tillers and also related with yield traits by increasing the no. of grains per spike. Among the four traits leaf area having high values in $\mathrm{PCl}$ are contributing towards total diversity. The results of PCA at spike initiation stage in field experiment of wheat varieties depicted that PC1 itself accounted 96.10 per cent of variation among all the principal components (PCs). Also, it had $>1.00$ eigen value (1.62) and it is significant among all 4 PCs (Table 2). $\mathrm{PC} 1$ is mainly correlated with leaf area and it is important component in PC1 with highest loading factor (0.96). So, leaf area is in direct relation with increase in the crop canopy with more number of tillers and also related with yield traits by increasing the no. of grains per spike. Among the four traits leaf area having high values in PC1 are contributing towards total diversity. The results of PCA at maximum tillering stage in pot experiment of wheat varieties depicted that PC1 itself accounted 89.18 per cent of variation among all the principal components (PCs). Also, it had $>1.00$ eigen value (1.23) and it is significant among all 4 PCs (Table 3). PC1 is mainly correlated with leaf area, leaf area index (LAI) and it is important component in PC1 with highest loading factor $(0.70,0.68)$. So, leaf area and leaf area index is in direct relation with increase in the crop canopy with more number of tillers and also related with yield traits by increasing the no. of grains per spike. Among the four traits leaf area, LAI having high values in $\mathrm{PC} 1$ are contributing towards total diversity. The results of PCA at spike initiation stage in pot experiment of wheat varieties depicted that $\mathrm{PC} 1$ itself accounted 84.37 per cent of variation among all the principal components (PCs). Also, it had $>1.00$ eigen value (1.21) and it is significant among all 4 PCs (Table 4). PC1 is mainly correlated with leaf area and it is important component in PC1 with highest loading factor (0.86). So, leaf area is in direct relation with increase in the crop canopy with more number of tillers and also related with yield traits by increasing the no. of grains per spike. Among the four traits leaf area, LAI having high values in PC1 are contributing towards total diversity. The results of PCA at maximum tillering stage in field experiment of wheat treatments depicted that PC1 itself accounted 98.28 per cent of variation among all the principal components (PCs). Also, it had $>1.00$ eigen value (2.3) and it is significant among all 4 PCs (Table 5). PC1 is mainly correlated with leaf area and LAI it is important component in PC1 with highest loading factor $(0.92)$. So, leaf area is in direct relation with increase in the crop canopy with more number of tillers and also related with yield traits by increasing the no. of grains per spike. Among the four traits leaf area having high values in $\mathrm{PC} 1$ are contributing towards total diversity.

The results of PCA at spike initiation stage in field experiment of wheat treatments depicted that PC1 itself accounted 99.21 per cent of variation among all the principal components (PCs). Also, it had $>1.00$ eigen value (2.05) and it is significant among all 4 PCs (Table 6). PC1 is mainly correlated with leaf area and it is important component in PC1 with highest loading factor (0.93). So, leaf area is in direct relation with increase in the crop canopy with more number of tillers and also related with yield traits by increasing the no. of grains per spike. Among the four traits leaf area having high values in PC1 are contributing towards total diversity. The results of PCA at maximum tillering stage in field experiment of wheat treatments depicted that PC1 itself accounted 95.47 per cent of variation among all the principal components (PCs). Also, it had $>1.00$ eigen value (1.94) and it is significant among all 4 PCs (Table 7). PC1 is mainly correlated with leaf area and LAI it is important component in PC1 with highest loading factor $(0.90,0.4)$. So, leaf area, LAI is in direct relation with increase in the crop canopy with more number of tillers and also 
Table 1: Principal component analysis and Mean performance of wheat varieties effect on Morphological Parameters at maximum tillering in field expt.

\begin{tabular}{|l|l|l|l|l|}
\hline SN & PC1 & PC2 & PC3 & PC4 \\
\hline Eigenvalue & 1.941142 & 0.014904 & 0.005258 & 0.001519 \\
\hline $\begin{array}{l}\text { Variance } \\
(\%)\end{array}$ & 97.748 & 1.5479 & 0.54608 & 0.15781 \\
\hline \multicolumn{5}{|l|}{ Traits Eigenvector } \\
\hline Leaf area & 0.91946 & 0.22685 & -0.29636 & -0.1237 \\
\hline $\begin{array}{l}\text { Leaf area } \\
\text { index }\end{array}$ & 0.17897 & 0.26493 & 0.89174 & -0.3203 \\
\hline $\begin{array}{l}\text { Specific } \\
\text { leaf weight }\end{array}$ & 0.080867 & 0.40146 & 0.18535 & 0.89327 \\
\hline $\begin{array}{l}\text { Tiller } \\
\text { Number }\end{array}$ & 0.34062 & -0.84686 & 0.28744 & 0.29013 \\
\hline
\end{tabular}

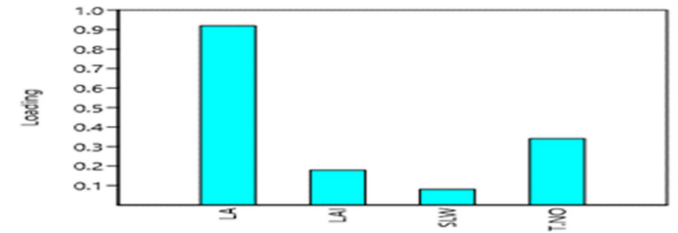

Figure 1: The principal component and loading plot analysis for PC1, PC2, PC3, and PC4 based on the trait means.

Table 2: Principal Component Analysis and Mean performance of wheat varieties effect on Morphological Parameters at spike initiation stages in field expt.

\begin{tabular}{|l|l|l|l|l|}
\hline SN & PC1 & PC2 & PC3 & PC4 \\
\hline Eigenvalue & 1.6217 & 0.019195 & 0.005787 & 0.000187 \\
\hline $\begin{array}{l}\text { Variance } \\
(\%)\end{array}$ & 96.109 & 2.9673 & 0.89456 & 0.028893 \\
\hline Traits Eigenvector & \multicolumn{5}{|l|}{} \\
\hline Leaf area & 0.96266 & -0.20667 & 0.04451 & -0.16911 \\
\hline $\begin{array}{l}\text { Leaf area } \\
\text { index }\end{array}$ & 0.21983 & 0.65945 & -0.66621 & 0.27012 \\
\hline $\begin{array}{l}\text { Specific } \\
\text { leaf weight }\end{array}$ & 0.098486 & 0.71102 & 0.68433 & -0.12819 \\
\hline $\begin{array}{l}\text { Tiller } \\
\text { Number }\end{array}$ & 0.12356 & -0.12983 & 0.29304 & 0.93915 \\
\hline
\end{tabular}

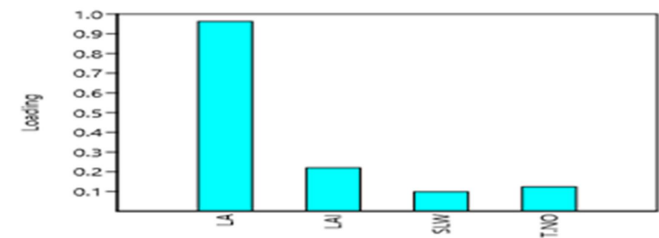

Figure 2: The principal component and loading plot analysis for PC1, PC2, PC3, and PC4 based on the trait means.
Table 3: Principal component analysis and Mean performance of wheat varieties effect on Morphological Parameters at maximum tillering in Pot expt.

\begin{tabular}{|l|l|l|l|l|}
\hline SN & PC1 & PC2 & PC3 & PC4 \\
\hline Eigenvalue & 1.23809 & 0.145781 & 0.003703 & 0.000615 \\
\hline $\begin{array}{l}\text { Variance } \\
(\%)\end{array}$ & 89.187 & 10.502 & 0.26674 & 0.044285 \\
\hline \multicolumn{5}{|l|}{ Traits Eigenvector } \\
\hline Leaf area & 0.70404 & 0.64412 & -0.29008 & -0.07275 \\
\hline $\begin{array}{l}\text { Leaf area } \\
\text { index }\end{array}$ & 0.68522 & -0.72479 & 0.062562 & -0.03534 \\
\hline $\begin{array}{l}\text { Specific } \\
\text { leaf weight }\end{array}$ & 0.16247 & 0.16248 & 0.55454 & 0.7998 \\
\hline $\begin{array}{l}\text { Tiller } \\
\text { Number }\end{array}$ & 0.091659 & 0.18276 & 0.77745 & -0.59479 \\
\hline
\end{tabular}

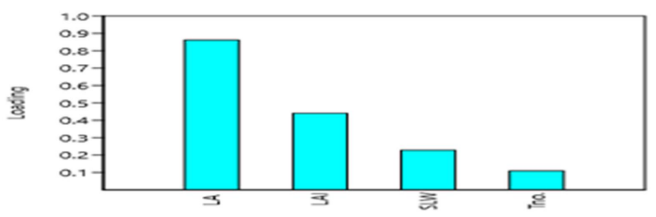

Figure 3: The principal component and loading plot analysis for PC1, PC2, PC3, and PC4 based on the trait means.

Table 4: Principal component analysis and Mean performance of wheat varieties effect on Morphological Parameters at spike initiation stage in Pot expt.

\begin{tabular}{|l|l|l|l|l|}
\hline SN & PC1 & PC2 & PC3 & PC4 \\
\hline Eigenvalue & 1.21955 & 0.206511 & 0.018304 & 0.000992 \\
\hline $\begin{array}{l}\text { Variance } \\
(\%)\end{array}$ & 84.377 & 14.288 & 1.2664 & 0.068665 \\
\hline \multicolumn{5}{|l|}{ Traits Eigenvector } \\
\hline Leaf area & 0.86139 & -0.29841 & -0.4082 & -0.0483 \\
\hline $\begin{array}{l}\text { Leaf area } \\
\text { index }\end{array}$ & 0.44045 & 0.8373 & 0.32178 & -0.03729 \\
\hline $\begin{array}{l}\text { Specific } \\
\text { leaf weight }\end{array}$ & 0.22822 & -0.45093 & 0.83635 & -0.21235 \\
\hline $\begin{array}{l}\text { Tiller } \\
\text { Number }\end{array}$ & 0.10919 & -0.08095 & 0.17419 & 0.97529 \\
\hline
\end{tabular}

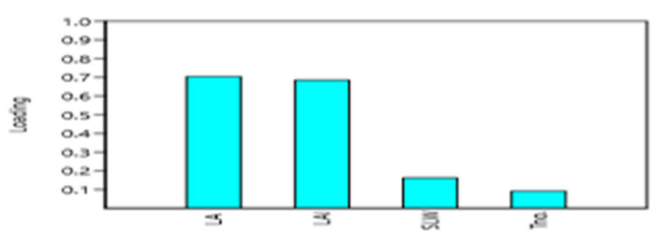

Figure 4: The principal component and loading plot analysis for PC1, PC2, PC3, and PC4 based on the trait means. 
related with yield traits by increasing the no. of grains per spike. Among the four traits leaf area having high values in $\mathrm{PC} 1$ are contributing towards total diversity. The results of PCA at spike initiation stage in pot experiment of wheat treatments depicted that PC1 itself accounted 95.25 per cent of variation among all the principal components (PCs). Also, it had $>1.00$ eigen value (1.75) and it is significant among all 4 PCs (Table $8)$. PC1 is mainly correlated with leaf area and it is important component in PC1 with highest loading factor (0.89). So, leaf area is in direct relation with increase in the crop canopy with more number of tillers and also related with yield traits by increasing the no. of grains per spike. Among the four traits having high values in PC1 are contributing towards total diversity. The results of PCA at spike initiation stage in field experiment of wheat varieties depicted that PC1 itself accounted 87.85 per cent of variation among all the principal components (PCs). Also, it had $>1.00$ eigen value (4.64) and it is significant among all 4 PCs (Table 9). PC1 is mainly correlated with Number of seeds per spike, and Test weight it is important component in $\mathrm{PC} 1$ with highest loading factor $(0.74,0.66)$. So, Number of seeds per spike, and Test weight is in direct relation with increase in the related with yield traits spike. Among the four traits having high values in $\mathrm{PC} 1$ are contributing towards total diversity.

The results of PCA at spike initiation stage in pot experiment of wheat varieties depicted that $\mathrm{PC1}$ itself accounted 88.79 per cent of variation among all the principal components (PCs). Also, it had $>1.00$ eigen value (3.6) and it is significant among all 4 PCs (Table 10). PC1 is mainly correlated with Number of seeds per spike it is important component in PC1 with highest loading factor (0.87). So, Number of seeds per spike, is in direct relation with increase in the with yield traits by increasing the no. of grains per spike. Among the four traits having high values in PC1 are contributing towards total diversity. The results of PCA at spike initiation stage in field experiment of wheat treatments depicted that PC1 itself accounted 93.11 per cent of variation among all the principal components (PCs). Also, it had $>1.00$ eigen value (1.9) and it is significant among all 4 PCs (Table 11). PC1 is mainly correlated with Number of seeds per spike, harvest index, test weight, biological index it is important component in $\mathrm{PC} 1$ with highest loading factor $(0.79,0.6,0.03,0.01)$. So, Number of seeds per spike, harvest index, test weight, biological index is in direct relation with increase in the with yield traits. Among the four traits having high values in $\mathrm{PC} 1$ are contributing towards total diversity.

The results of PCA at spike initiation stage in pot experiment of wheat treatments depicted that PC1 itself accounted 64.42 per cent of variation among all the principal components (PCs). Also, it had $>1.00$ eigen value (1.31) and it is significant among all 4 PCs (Table 11). PC1 is mainly correlated with Length of the spike, Spike weight, test weight it is important component in $\mathrm{PC} 1$ with highest loading factor $(0.08,0.08,0.7)$. So, Length of the spike, Spike weight, test weight is in direct relation with increase in the with yield traits. Among the four traits having high values in $\mathrm{PC} 1$ are contributing towards total diversity. In the field experiment, seed number per spike increased significantly due to the Sulphur aerosols. Among the aerosols treatments, the highest increment in seed number per spike was shown by $\left(\mathrm{NH}_{4}\right)_{2} \mathrm{SO}_{4}(15.3 \%)$ followed by $\mathrm{CaSO}_{4}$ $(9.7 \%)$, and the lowest was shown by $\mathrm{K}_{2} \mathrm{SO}_{4}(7.7 \%)$ as compared to control. Eigen value of (1.91) accounting for $(93.117 \%)$ of the total variance. Among the varieties the highest increment in seed number per spike was shown by GW-366 (40.215) > GW- 273 (39.58) > GW-322 (39.095) $>\mathrm{GW}-173$ (38.021), and the lowest number of seed was observed in JW-336 (36.084). Eigen value of (4.64) accounting for $(87.851 \%)$ of the total variance. Tea et al., (1990) stated a synergistic effect, of the foliar-applied N, and S fertilizers that appears to increase their number of grains per ear, number of spikes per plant, and assimilates in grain. The probable reason may be due to the maximum availability and absorption of sulphur in case of foliar spray that resulted in more grains spike (Garcia del Moral et al., 1991; Ramos et al., 1995). Yield gains obtained from sulphur fertilization ranged between $280 \& 310 \mathrm{~kg} \mathrm{ha}^{-1}(+7 \%)$.

In the field experiment, Spike weight increased significantly due to the Sulphur aerosols. Among the aerosols, the highest increment in Spike weight was shown by $\left(\mathrm{NH}_{4}\right)_{2} \mathrm{SO}_{4}(23 \%)$ followed by $\mathrm{K}_{2} \mathrm{SO}_{4}(19.2 \%)$, and the lowest was shown by 
Table 5: Principal component analysis and Mean performance of wheat Treatments effect on Morphological Parameters at maximum tillering in Field expt.

\begin{tabular}{|l|l|l|l|}
\hline SN & PC1 & PC2 & PC3 \\
\hline Eigenvalue & 2.39725 & 0.034087 & 0.00764 \\
\hline Variance (\%) & 98.289 & 1.3976 & 0.31324 \\
\hline Traits & \multicolumn{4}{|c|}{ Eigenvector } \\
\hline Leaf area & 0.92944 & -0.19045 & -0.28601 \\
\hline Leaf area index & 0.091625 & -0.06505 & -0.12226 \\
\hline Specific leaf weight & 0.20355 & -0.39485 & 0.89349 \\
\hline Tiller Number & 0.29377 & 0.89643 & 0.32392 \\
\hline
\end{tabular}

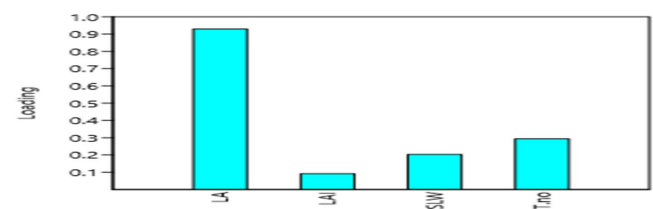

Figure 5: The principal component and loading plot analysis for PC1, PC2, PC3, and PC4 based on the trait means.

Table 6: Principal component analysis and Mean performance of wheat Treatments effect on Morphological Parameters at spike initiation stage in field expt.

\begin{tabular}{|l|l|l|l|}
\hline SN & PC1 & PC2 & PC3 \\
\hline Eigenvalue & 2.05026 & 0.015947 & 0.000372 \\
\hline Variance (\%) & 99.21 & 0.77168 & 0.017988 \\
\hline Traits Eigenvector \\
\hline Leaf area & 0.93288 & -0.24323 & -0.22984 \\
\hline Leaf area index & 0.11743 & -0.29975 & 0.2673 \\
\hline Specific leaf weight & 0.23292 & 0.89739 & -0.19118 \\
\hline Tiller Number & 0.2484 & 0.21372 & 0.91607 \\
\hline
\end{tabular}

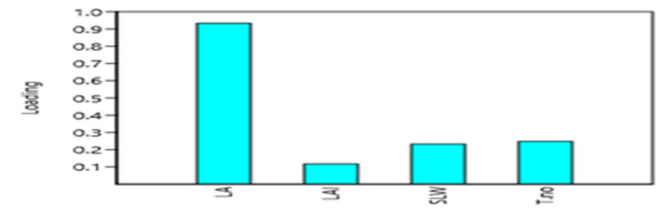

Figure 6: The principal component and loading plot analysis for PC1, PC2, PC3, and PC4 based on the trait means.

$\mathrm{CaSO}_{4}(5.7 \%)$ as compared to control. Eigen value of (1.91) accounting for $(93.117 \%)$ of the total variance. Among the varieties the highest increment in seed number per spike was shown by variety GW-273 (2.288 g) > GW-366 (2.25 g) > GW- $173(2.225 \mathrm{~g})>\mathrm{JW}-336(2.025 \mathrm{~g})$, while the lowest was observed in GW-322 (1.963 g). Eigen value of (4.64) accounting for (87.851\%). effect of foliar sulphur aerosols spike weight is correlated with no. of spikelet's (Zebrath et al., 1992)

In the field experiment, Test weight $(\mathrm{g})$ increased significantly due to the Sulphur aerosols. Among the aerosols, the highest increment in Test weight was shown by $\left(\mathrm{NH}_{4}\right)_{2} \mathrm{SO}_{4} \quad(11.8 \%)$ followed byK $\mathrm{SO}_{4}(4.9 \%)$, and the lowest was shown byCaSO$_{4}(3.6 \%)$ as compared to control. Eigen value of (1.91) accounting for (93.117\%) of the total variance. Among the varieties the highest increment in seed number per spike was shown by variety GW-366 (40.07g) $>$ GW-273 (39.319g) $>$ GW- $322(38.293 \mathrm{~g})>\mathrm{GW}-173(37.164 \mathrm{~g})$, and the lowest was seen in JW-336(36.534g). Eigen value of (4.64) accounting for $(87.851 \%)$ of the total variance. Soylu et al., (2005) Application of N, and $\mathrm{S}$ resulted a significant increase in 1000 grain weight. The heavier grain weight may be due to the efficient metabolic activities which increased the gluten content in grain and improves nutritional status. Whereas foliar sulphur application slightly increased test weight from 79.9 to $81 \mathrm{~kg} \mathrm{~h}^{-1}$. In the field experiment, HI increased significantly due to the Sulphur aerosols Among the aerosols, the highest increment in $\mathrm{HI}$ was shown by $\left(\mathrm{NH}_{4}\right)_{2} \mathrm{SO}_{4}$ $(28.7 \%)$ followed by $\mathrm{CaSO}_{4}(23 \%)$, and the lowest was shown by $\mathrm{K}_{2} \mathrm{SO}_{4}(17.3 \%)$ as compared to control. Eigen value of (1.91) accounting for $(93.117 \%)$ of the total variance. Among the varieties the highest increment in seed number per spike was shown by variety GW- $366(0.846 \%)$ followed by GW-322 (0.839 \%) GW-273 (0.811\%) GW-173 (0.77\%), and the lowest was seen in JW$336(0.733 \%)$. Eigen value of (4.64) accounting for $(87.851 \%)$ of the total variance. S application significantly enhanced wheat yield and yield components. This is because $\mathrm{Ca}$, and $\mathrm{S}$ contents enhance the availability of macro, and micronutrients due to synergic effect on plant growth. However, $\mathrm{Ca}$, and $\mathrm{S}$ help to maintain $\mathrm{K}$ concentration in plants, and thereby healthy crop stand due to increased nutrient use efficiency (Prasad, 2003; Ali et al., 2008).

In the field experiment, biological yield increased significantly due to the Sulphur aerosols Among the aerosols, the highest increment in biological yield was shown by $\left(\mathrm{NH}_{4}\right)_{2} \mathrm{SO}_{4}(9.38 \%)$ followed by $\mathrm{K}_{2} \mathrm{SO}_{4}(3.8 \%)$, and the lowest was shown by $\mathrm{CaSO}_{4}$ $(3.55 \%)$ as compared to control. Eigen value of (1.91) accounting for $(93.117 \%)$ of the total 
Table 7: Principal Component Analysis and Mean performance of wheat Treatments effect on Morphological Parameters at maximum tillering in Pot expt.

\begin{tabular}{|l|l|l|l|}
\hline SN & PC1 & PC2 & PC3 \\
\hline Eigenvalue & 1.94336 & 0.077813 & 0.014407 \\
\hline Variance (\%) & 95.47 & 3.8227 & 0.70777 \\
\hline Traits Eigenvector \\
\hline Leaf area & 0.90204 & -0.40596 & -0.1318 \\
\hline Leaf area index & 0.40177 & 0.91373 & -0.04443 \\
\hline Specific leaf weight & 0.088387 & 0.010307 & 0.088093 \\
\hline Tiller Number & 0.13074 & -0.01401 & 0.98635 \\
\hline
\end{tabular}

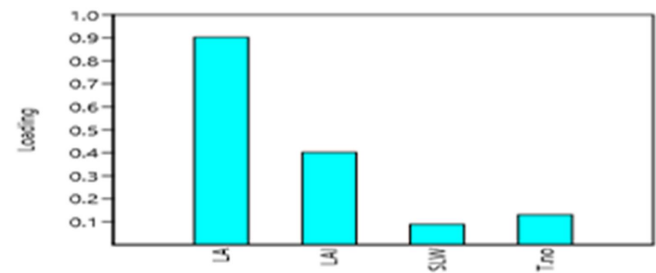

Figure 7: The principal component and loading plot analysis for PC1, PC2, and PC3 based on the trait means.

Table 8: Principal Component Analysis and Mean performance of wheat Treatments effect on Morphological Parameters at spike initiation stage in Pot expt.

\begin{tabular}{|l|l|l|l|}
\hline SN & PC1 & PC2 & PC3 \\
\hline Eigenvalue & 1.75564 & 0.072967 & 0.014411 \\
\hline Variance (\%) & 95.259 & 3.9591 & 0.78194 \\
\hline Traits Eigenvector \\
\hline Leaf area & 0.89377 & -0.44125 & -0.06147 \\
\hline Leaf area index & 0.42653 & 0.87663 & -0.18951 \\
\hline Specific leaf weight & 0.075755 & 0.18336 & 0.49749 \\
\hline Tiller Number & 0.11618 & 0.056601 & 0.84428 \\
\hline
\end{tabular}

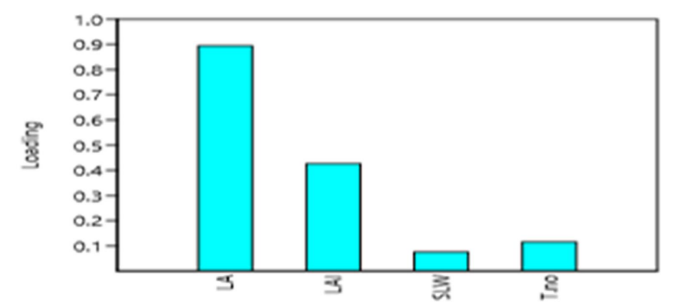

Figure 8: The principal component and loading plot analysis for PC1, PC2, PC3, and PC4 based on the trait means.
Table 9: Principal Component Analysis and Mean performance of wheat varieties effect on yield and yield attributes at spike initiation stages in field expt.

\begin{tabular}{|c|c|c|c|c|}
\hline SN & PC1 & PC2 & PC3 & PC4 \\
\hline Eigenvalue & 4.6458 & 0.539206 & 0.100112 & 0.003127 \\
\hline $\begin{array}{l}\text { Variance } \\
(\%)\end{array}$ & 87.851 & 10.196 & 1.8931 & 0.059126 \\
\hline \multicolumn{5}{|c|}{ Traits Eigenvector } \\
\hline $\begin{array}{l}\text { Number of } \\
\text { seeds per } \\
\text { spike }\end{array}$ & 0.7427 & -0.17512 & 0.63661 & -0.09677 \\
\hline $\begin{array}{l}\text { Length of } \\
\text { the spike } \\
(\mathrm{cm})\end{array}$ & -0.01248 & 0.95216 & 0.24859 & -0.17643 \\
\hline $\begin{array}{l}\text { Spike } \\
\text { weight (g) }\end{array}$ & 0.035313 & 0.1371 & 0.16006 & 0.9501 \\
\hline $\begin{array}{l}\text { Test } \\
\text { weight }\end{array}$ & 0.66761 & 0.20704 & -0.71129 & 0.065041 \\
\hline HI (\%) & 0.020467 & -0.02128 & -0.00162 & -0.17532 \\
\hline $\begin{array}{l}\text { BY (t ha - } \\
\text { 1) }\end{array}$ & 0.024787 & -0.01477 & -0.03139 & -0.06355 \\
\hline $\begin{array}{l}\text { EY (t ha- } \\
\text { 1) }\end{array}$ & 0.016026 & -0.01982 & 0.019688 & -0.1335 \\
\hline
\end{tabular}

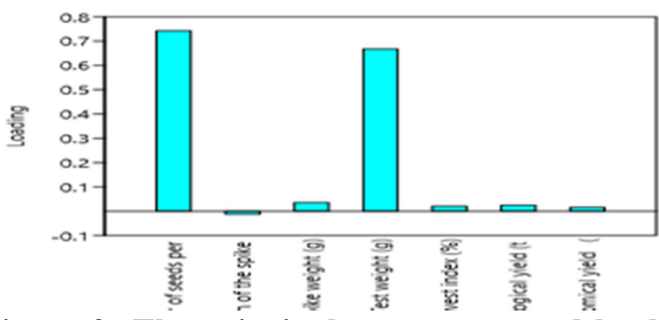

Figure 9: The principal component and loading plot analysis for PC1, PC2, PC3, and PC4 based on the trait means.

Table 10: Principal Component Analysis and Mean performance of wheat varieties effect on yield and yield attributes at spike initiation stages in pot expt.

\begin{tabular}{|c|c|c|c|c|}
\hline SN & PC1 & PC2 & PC3 & PC4 \\
\hline Eigenvalue & 3.66409 & 0.302245 & 0.154774 & 0.005372 \\
\hline Variance (\%) & 88.795 & 7.3245 & 3.7507 & 0.13019 \\
\hline \multicolumn{5}{|c|}{ Traits Eigenvector } \\
\hline $\begin{array}{l}\text { Number of } \\
\text { seeds per } \\
\text { spike }\end{array}$ & 0.87614 & -0.30772 & 0.20117 & -0.13203 \\
\hline $\begin{array}{l}\text { Length of } \\
\text { the spike } \\
(\mathrm{cm})\end{array}$ & 0.12326 & 0.28442 & -0.79761 & -0.03148 \\
\hline $\begin{array}{l}\text { Spike } \\
\text { weight (g) }\end{array}$ & 0.019037 & 0.20325 & 0.33189 & 0.52001 \\
\hline Test weight & 0.4643 & 0.51359 & -0.17085 & 0.17357 \\
\hline HI (\%) & -0.01465 & 0.12011 & 0.071466 & -0.37708 \\
\hline BY (t ha -1) & -0.01097 & 0.70822 & 0.42224 & -0.31013 \\
\hline $\begin{array}{l}\text { EY (t ha- } \\
\text { 1) }\end{array}$ & 0.030274 & 0.057753 & 0.024665 & 0.66534 \\
\hline
\end{tabular}




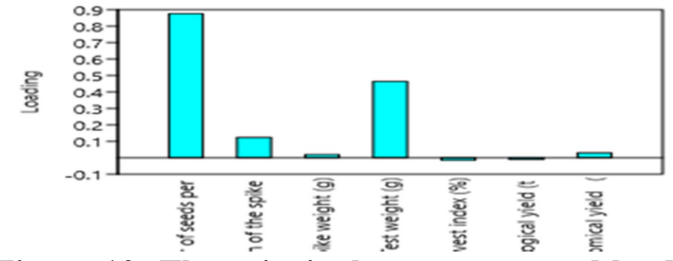

Figure 10: The principal component and loading plot analysis for PC1, PC2, PC3, and PC4 based on the trait means

Table 11: Principal component analysis and Mean performance of wheat treatments effect on yield and yield attributes at spike initiation stages in field expt.

\begin{tabular}{|l|l|l|l|}
\hline SN & PC1 & PC2 & PC3 \\
\hline Eigenvalue & 1.9129 & 0.734673 & 0.071932 \\
\hline Variance (\%) & 93.117 & 6.2688 & 0.61378 \\
\hline \multicolumn{4}{|l|}{} \\
\hline $\begin{array}{l}\text { Traits Eigenvector } \\
\text { Number of seeds } \\
\text { per spike }\end{array}$ & 0.79041 & -0.39747 & 0.40963 \\
\hline $\begin{array}{l}\text { Length of the spike } \\
\text { (cm) }\end{array}$ & 0.016533 & 0.76927 & 0.5649 \\
\hline Spike weight (g) & 0.067402 & 0.047644 & -0.51625 \\
\hline Test weight & 0.60683 & 0.495 & -0.49473 \\
\hline HI (\%) & 0.032322 & -0.03726 & 0.030005 \\
\hline BY (t ha -1) & 0.016733 & 0.01072 & 0.001802 \\
\hline EY (t ha-1) & 0.029589 & -0.03805 & 0.030409 \\
\hline
\end{tabular}

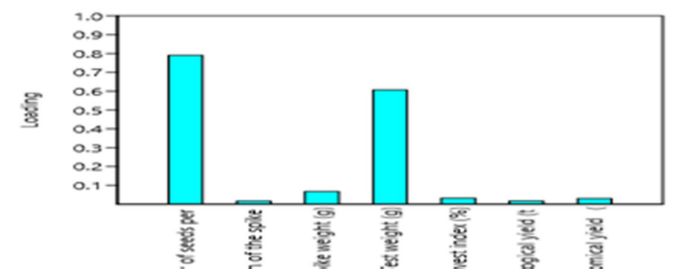

Figure 11: The principal component and loading plot analysis for PC1, PC2, and PC3 based on the trait means.

Table 12: Principal Component analysis and Mean performance of wheat treatments effect on yield and yield attributes at spike initiation stages in pot expt.

\begin{tabular}{|l|l|l|l|}
\hline SN & PC1 & PC2 & PC3 \\
\hline Eigenvalue & 1.31843 & 0.59709 & 0.13082 \\
\hline Variance (\%) & 64.429 & 29.178 & 6.3929 \\
\hline \multicolumn{4}{|l|}{ Traits Eigenvector } \\
\hline $\begin{array}{l}\text { Number of seeds } \\
\text { per spike }\end{array}$ & 0.47101 & 0.75491 & -0.39661 \\
\hline $\begin{array}{l}\text { Length of the } \\
\text { spike (cm) }\end{array}$ & 0.087969 & -0.15912 & -0.06519 \\
\hline Spike weight $(\mathrm{g})$ & 0.084243 & 0.083642 & -0.10132 \\
\hline Test weight & 0.72747 & -0.56628 & -0.29413 \\
\hline HI (\%) & 0.025 & -0.10172 & 0.011226 \\
\hline BY (t ha -1) & 0.45401 & 0.052963 & 0.78307 \\
\hline EY (t ha-1) & 0.16537 & 0.25293 & 0.35826 \\
\hline
\end{tabular}

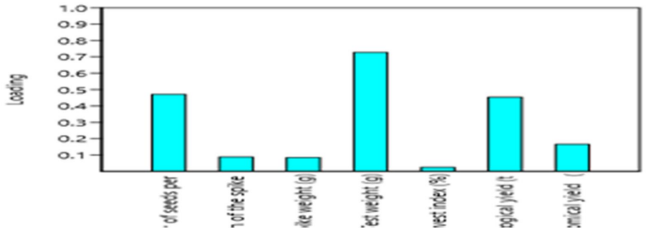

Figure 12: The principal component and loading plot analysis for Number of seeds per spike, Length of the spike (cm), Spike weight (g), Test weight $(\mathrm{g})$, Harvest index (\%),Biological yield (t ha -1), Economical yield (t ha-1) based on the trait means

variance. Among the varieties the highest increment in seed number per spike was shown by variety The maximum biological yield was observed in the variety GW-366 (1.334 $\left.\mathrm{t} \mathrm{ha}^{-1}\right)$ followed by GW-273 (1.308 $\left.\mathrm{t} \mathrm{ha}^{-1}\right), \mathrm{GW}-322$ (1.308t ha $\mathrm{ha}^{-1}$ GW-173 $\left(1.228 \mathrm{t} \mathrm{ha}^{-1}\right)$, and the lowest was recorded in JW$336\left(1.208 \mathrm{tha}^{-1}\right)$. Eigen value of (4.64) accounting for $(87.851 \%)$ of the total variance. Foliar application of sulphur improves dough mixing properties it increases grain yield and straw yield (Tea et al., 2004). In the field experiment economic yield increased significantly due to the Sulphur aerosols. Among the aerosols, the highest increment in biological yield was shown by $\left(\mathrm{NH}_{4}\right)_{2} \mathrm{SO}_{4}(27.3 \%)$ followed by $\mathrm{CaSO}_{4}(22.4 \%)$, and the lowest was shown by $\mathrm{K}_{2} \mathrm{SO}_{4}(16.6 \%)$ as compared to control. Eigen value of (1.91) accounting for $(93.117 \%)$ of the total variance. Among the aerosols, the highest increment is shown by variety GW-322( $\left.0.814 \mathrm{tha}^{-1}\right)$ followed by GW-366(0.812 $\left.\mathrm{t} \mathrm{ha}^{-1}\right)>\mathrm{GW}-273\left(0.787 \mathrm{t} \mathrm{ha}^{-1}\right)$ $>$ GW- $173\left(0.767 \mathrm{tha}^{-1}\right)$, and the lowest was recorded in JW-336 $\left(0.72 \mathrm{t} \mathrm{ha}^{-1}\right)$. Eigen value of (4.64) accounting for $(87.851 \%)$ of the total variance. foliar spraying of spring wheat with nitrogen, and sulphur fertilizers -ammonium sulphate, especially when there is low content of plant available sulphur in the soil. Positive interaction of foliar $\mathrm{S}$ with $\mathrm{N}$ have reportedly augmented yield to over control levels in different cereals (Scott et al., 1984)

\section{Conclusion}

In the present work, In the Field \& Pot experiments, number of seed per spike, spike weight, TW, EY, and BY varied significantly among the varieties and treatments. The variety GW-366 followed by 273 
emerged as the most efficient genotype Further, as regard to the field application of sulfur aerosols, $\left(\mathrm{NH}_{4}\right)_{2} \mathrm{SO}_{4}$ was more effective than $\mathrm{CaSO}_{4}$ and $>\mathrm{K}_{2} \mathrm{SO}_{4}$ and controlled distilled water. Thus, among the aerosols, $\left(\mathrm{NH}_{4}\right)_{2} \mathrm{SO}_{4}$ applied as foliar spray to explore the potential economic yield. Foliar applied

\section{References}

Burney, J., \& Ramanathan, V. (2014). Recent climate and air pollution impacts on Indian agriculture. Proceedings of the National Academy of Sciences, 111(46), 16319-16324.

Chameides, W. L., Yu, H., Liu, S. C., Bergin, M., Zhou, X., Mearns, L., \& Giorgi, F. (1999). Case study of the effects of atmospheric aerosols and regional haze on agriculture: an opportunity to enhance crop yields in China through emission controls?. Proceedings of the National Academy of Sciences, 96(24), 13626-13633.

Chen, Y., Zhang, Z., \& Tao, F. (2018). Impacts of climate change and climate extremes on major crops productivity in China at a global warming of 1.5 and 2.0 C. Earth System Dynamics, 9(2), 543-562.

DES (2017). Directorate of Economics and Statistics, Pocket book on Agricultural statistics, Department of Agriculture and Cooperation, Ministry of Agriculture, Government of India, New Delhi.

FAO (2018). Food Outlook Biannual Report on Global Food Markets. Food and Agriculture Organization of the United Nations.

FAO (2017). India Country Programming Framework. Food and Agriculture Organization of the United Nations. nutrients are better rather than soil application shows fast recovery for farmer.

\section{Acknowledgement}

The authors express sincere gratitude to Assam Agricultural University (AAU) for all kinds of support for conducting the experiment.

Hu, B., Zhao, X., Liu, H., Liu, Z., Song, T., Wang, Y., \& Xin, J. (2017). Quantification of the impact of aerosol on broadband solar radiation in North China. Scientific reports, $7(1), 1-8$.

Lobell, D. B., Hammer, G. L., McLean, G., Messina, C., Roberts, M. J., \& Schlenker, W. (2013). The critical role of extreme heat for maize production in the United States. Nature climate change, 3(5), 497-501.

Lobell, D. B., Schlenker, W., \& Costa-Roberts, J. (2011). Climate trends and global crop production since 1980. Science, 333(6042), 616-620.

Myhre, G., Samset, B. H., Schulz, M., Balkanski, Y., Bauer, S., Berntsen, T. K., \& Zhou, C. (2013). Radiative forcing of the direct aerosol effect from AeroCom Phase II simulations. Atmospheric Chemistry and Physics, 13(4), 1853-1877.

Petäjä, T., Järvi, L., Kerminen, V. M., Ding, A. J., Sun, J. N., Nie, W., \& Kulmala, M. (2016). Enhanced air pollution via aerosol-boundary layer feedback in China. Scientific reports, 6(1), 1-6..

UN (2017). United Nations, Department of Economic and Social Affairs, Population Division. World Population Prospects: The Revision, Key Findings and Advance $\mathrm{ESA} / \mathrm{P} / \mathrm{WP} / 248$ 